\title{
ИСКАЖЕНИЕ СЛАВЯНСКИХ МИФОЛОГИЧЕСКИХ ОБРАЗОВ В КОМПЬЮТЕРНЫХ ИГРАХ
}

\author{
(с точки зрения русской языковой картины мира)
}

\begin{abstract}
Настоящая статья рассматривает искажение славянских мифологических образов в компьютерных играх из серии «Ведьмак» с точки зрения русской языковой картины мира. В paботе сравнивается репрезентация славянских мифонимов в бестиарии игры и традиционное восприятие этих образов в языковой картине мира русских.

Ключевые слова: мифоним, русская языковая картина мира, славянские образы, компьютерные игры, искажение образов.
\end{abstract}

This work explores the distortion of Slavic mythological characters in the computer game series The Witcher. The work compares the representation of Slavic mythonyms in the game's bestiary and the traditional perception of these characters in the Russian linguistic worldview.

Keywords: mythonyms, Russian linguistic worldview, Slavic characters, computer games, distortion of characters.

В мире высоких технологий человек подвержен постоянной культурной интерференции, глобализации и трансформации. Быстро меняющаяся среда оказывает влияние на его перцепцию, мышление и поведение. Грань между реальным и виртуальным стирается до такой степени, что обычными стали понятия «компьютерная реальность», «виртуальная реальность», обозначающие на самом деле нечто нереальное. И если XX век дал миру феномен «homo ludens» («человек играющий» по Хеизинге), то XXI век «апгрейдовал» этого человека играющего, вывел его на высокотехнологичный уровень и превратил в геймера.

По статистическим данным Intel за 2015 год 1,8 млрд. человек можно считать геймерами ${ }^{1}$. Один из самых популярных жанров компьютерных игр - это компьютерные ролевые игры (Computer Role-Playing Game, CRPG или RPG). B ролевых компьютерных играх мифология часто является ядром формирования альтернативного мира. В нем игрок, который является языковой личностью (по Ю. Н. Караулову), носителем определенной языковой картины мира, выступает в роли одного из персонажей и теоретически на определенное время меняет свою личность.

В данной работе рассмотрим, как мифологическая картина мира славян репрезентирована в компьютерных играх, и какое влияние оказывает эта репрезентация на языковую личность носителей русского языка.

${ }^{1}$ Информация указана на сайте https://3dnews.ru/918930 
В мифологической картине мира закодировано мифологическое сознание, проявляющееся в виде составляющих ее концептов. По определению Ю. С. Степанова концепт - это: «идея, включающая абстрактные, конкретно-ассоциативные и эмоционально-оценочные признаки, а также спрессованную историю понятия» (Степанов 1997: 41-42). В целях данной работы принимаем рабочее название мифологемы, которым будем обозначать концепты, т.е. невербальные единицы мифологической картины мира. Чтобы разграничить невербальные единицы от вербальных, вводим термин мифонимы. Вслед за Матвиенко под этим термином будем понимать «лексические единицы мифологического содержание, вербализующие концепты-мифологемы отдельного этноса и содержащие этноспецифическую информацию» (Матвиенко 2010: 43).

Рассмотрим соотношение мифоним - мифологема, а также искажение славянских образов в компьютерных играх в рамках русской языковой картины мира на примерах русской локализации популярной серии игр «Ведьмак» (Wiedźmin), созданных компанией CD Projekt Red по одноименной серии романов польского писателя Анджея Сапковского (Andrzej Sapkowski).

Исследователи творчества Сапковского выделяют высокую степень интертекстуальности и реконструкцию славянских образов как характерные особенности его стиля (Zaborowski 2015: 21-33). Наряду с этим надо отметить и т. наз. retelling (пересказ), как специфический для его произведений литературный прием. Милош Йоцич (Милош Јоцић) отмечает, что «в основе этих историй часто лежат польские, словенские и, вообще, европейские сказки или легенды, чьи действие, образы и мораль Сапковский сильно иронизирует, или как признается сам автор, трансвестирует» (Јоцић 2016: 301)2.

Д. Арестова выделяет три уровня его работы - уровень классической мифологии, уровень авторской мифологии и аналитический уровень. В рамках аналитического уровня она рассматривает созданный ими «Бестиарий» в двух частях и отмечает, что Сапковский сделал «попытку рефлексии, создавая нехудожественные произведения, обобщающие и систематизирующие сведения о мифологических персонажах» (Арестова 2012: 245).

Хотя бестиарий игр основан на произведениях Сапковского, будем рассматривать игры как отдельный продукт, а не как часть «Саги о ведьмаке» (Saga o wiedźminie). Сам автор в одном интервью подчеркивает: «Со всем уважением, но пора сказать это прямо - игры не являются «альтернативной версией» или сиквелом. Это свободная адаптация, содержащая элементы моих работ, адаптация, созданная другими авторами». ${ }^{3}$

В своем исследовании «Gra The Witcher w uniwersum Wiedźmina» Мария Гарда (Maria Garda) рассматривает перенос истории из романа в игру как перенос отдельных элементов сюжета и избранных героев. Творцом истории в игре является сам игрок, а не автор. В том смысле «Продукт CD Projekt не только встроен в созданном Анджеем Сапковским мире, но является его продолжением в новой среде» (Garda 2010: 21).

\footnotetext{
${ }^{2}$ Перевод наш. - Е.M.

${ }^{3}$ Интервью в переводе на русский язык публиковано на http://www.sapkowski.su/modules. php?name $=$ News \& file $=$ view $\&$ sid $=107$

Славистика XXII/2 (2018)
} 
С другой стороны, локализации игры для разных стран тоже следует рассматривать как отдельные продукты, так как в них существуют отличия не только от оригинального художественного текста Сапковского, но и от польской версии игры.

Материал для нашей работы эксцерпирован из описания бестиария русской локализации игр (далее - БРЛИ) ${ }^{4}$, которая адаптирована сообразно русской языковой картине мира.

Бестиарий «Ведьмака» насчитывает больше двухсот образов. Встречаются мифонимы из мифологических картин мира славян, евреев, индейцев, англосаксонцев, арабов, японцев, латиноамериканцев и т. д. Многие образы придуманы самим Сапковским. По названию и характеристикам они настолько похожи на реально существующие в мифологии, что трудно отличить их. Из всего бестиария мы выделили мифонимы, встречающиеся в языковой картине мира русских, чьи корни восходят к славянской мифологии, такие как бес, домовой, леший, полуденница, яга, волколак, кащей, кикимора. Чтобы выявить какие мифологемы стоят за этими мифонимами, и проследить искажение образов, мы сравним традиционное восприятие о них у носителей русского языка, зафиксированное в Мифологическом словаре 1991 г. под редакцией Е. М. Мелетинского (далее - МФС), и их описание в БРЛИ «Ведьмак».

Эксцерпированный материал можем распределить в две группы:

1. Искажённые образы (мифоним в некоторой степени не совпадает со славянской мифологемой)

Яга, домовой, бес, леший, волколак, полуденница,

2. Замененные образы (мифоним полностью не соответствует мифологеме)

кикимора, кащеей

\section{Искажённые образы}

\section{Яza}

Баба-Яга хорошо знакомый образ лесной старухи. Как антагонист, который противодействует главному герою, она является важным элементом процесса становления характера героя. В традиционном представлении русских она связана с несколькими обязательными атрибутами: костяная нога, слепота, избушка на курьих ножках и помел.

Ведьмаковская Яга, как и славянский первообраз - злая ведьма, но она разбивает стереотипы, отрицая именно обязательные атрибуты. По описанию в бестиарии игры «внешне она похожа на старую уродливую женщину, а также славится своей ведьминской вредностью. Эти твари питаются человечиной, и хотя они с удовольствием употребляют в пищу и трупь, предпочитают яги свежую и ещте теплую плоть. Яги охотятся по ночам и на время охоты собираются в группы, которые кметы называют «иабашами». Они любят обманывать своих жертв и издеваться над ними, но в рассказах о полетах на помеле и избушках на курьих ножках нет ни слова правдыл (БРЛИ).

${ }^{4}$ Не путать бестиарий игры с литературным произведением «Бестиарий» Сапковского, где автор рассматривает уже и канонические мифологические образы. 
Фольклорный мотив противоборства Бабы-Яги и доброго молодца появляется в игре, но в характере ведьмаковской Яги больше отсылок на ее чудовищную суть, чем в традиционном образе. По мнению В. Я. Проппа в славянском образе из сказок обнаруживаем черты похитительницы, воительницы, но и дарительницы, к которой приходит герой (Пропп 2000: 36-89). В физическом плане сразу замечается, что не хватает одной из основных характеристик славянской БабыЯги - костяной ноги.

Хотя образ в игре искажен, описание намекает на несовпадение со славянской мифологемой, что дает возможность игроку осознать, что существует другое, традиционное восприятие образа.

\section{Беc}

По данным МФС образ бесов для русских связан с языческими религиозно-мифологическими представлениями о злых духах: «В христианских религиозно-мифологических представлениях Б.- духи зла, антагонисты троичь и ангелов, слуги, воины и шпионы дьявола, «враги невидимые» человеческого рода. Как сеятели дурных внушений, болезней (особенно душевных расстройств - «беснования») и всякой скверны и порчи, как разрушители социальных связей» (МФС 1991). Бесы - это падшие ангелы. Распространено представление о бесах, предлагающих себя для блуда мужчине - в виде женщины («суккуб»), а женщине - в виде мужчины («инкуб»). Такое представление указывает на связывающую роль бесов между языческими традициями и христианством.

Ведьмаковские бесы - это «ходячая гора мускулов, увенчанная рогатой головой с пастью, полной острых зубов. Как и его более редкий родственник, бука, бес живет в густых чащах, в топях и на болотах. Когда это возможно, он избегает людей. Но если этого не удается, то убивает их безо всякого труда» (БРЛИ).

Отличия традиционного и игрового образов можно рассматривать в двух направлениях - в физическом плане и в их генезисе. Ведьмаковские бесы обладают физическими характеристиками полнокровных героев, что не соответствует традиционному представлению о бесплотности бесов. Что касается генезиса, в игре полностью утрачен религиозный элемент. Сохранена только языческая связь с суккубами.

\section{Домовой}

Мифоним «домовой» в русской локализации игры встречаем в двух разновидностях - домовой и домовой-доплер 5 .

1. домовой - «маленький человечек в остроконечной шляпе. В обмен на помощь по дому домовой получает миску молока, которую он выпивает поздно ночью» (БРЛИ).

2. домовой-доплер - «они становятся чрезвычайно опасными. Сражение с ними быстро превращается в бой с самим собой. Или, если точнее, с соб-

${ }^{5}$ В польской версии ему соответствует chochlik.

Славистика XXII/2 (2018) 
ственным зеркальным отражением, наделенным теми же умениями и слабостями» (БРЛИ).

У русских образ домового - образ духа дома. Он хранитель дома и от его благорасположения/ неблагорасположения зависит жизнь хозяев. По данным МФС «Представлялся в виде человека, часто на одно лицо с хозяином дома, или как небольшой старик с лицом, покрытылм белой шерстью» (МФС 1991). Возможность принимать облик хозяина роднит его с образом домового-доплера из «Ведьмака», а связь с домом - с первым видом ведьмаковских домовых. Традиционный образ «расчленен», а отдельные элементы распределены - социальные функции забирают на себя домовые, физические характеристики - домовой-доплер.

\section{Леший}

Образ лешего в игре один из самых достоверных. Он почти полностью совпадает с представлением духа леса, сложившимся в русской языковой картине мира. Он олицетворяет природу и у него антропозооморфные черты. Традиционный образ всегда враждебен человеку, в отличие от Ведьмаковского, который нападает только тех, кто оскорбляет природу.

\section{Волколак}

Славянские волколаки - оборотни, превращающиеся в волков. Мелетинский связывает волколаков со свадебным ритуалом.

«Считалось также, что колдуны могли превратить в волков целые свадебные поезда. Исключительная архаичность этих представлений явствует из того, что в других индоевропейских традициях (в частности, хеттской) превращение жениха в волка связывается с распространённой формой брака - умыканием (насильственным уводом невесты)» (МФС 1991).

В бестиарии «Ведьмака» на образ волколака заметное влияние оказал образ западноевропейского вервольфа.

Превращение в волка связано с луной, оно происходит против воли человека, который потом не помнит что делал. В советах, данных к игре, как справиться с волколаком, встречается: «Для борьбы с волколаками хорошо подойдёт меч, покрытый специиальным маслом от проклятых существ, или бомба, начинённая серебром, которая временно заблокирует их способность к регенерацчии» (БРЛИ)

Ведьмаковский волколак - сочетание славянского и западноевропейского представления об оборотнях.

\section{Полуденница}

Ведьмаковская полуденница соответствует славянской полуднице.

В бестиарии «Ведьмака» это разновидность призраков в виде бледной, истощенной девушки. «Полуденниць рождаются в полдень от жары, печали u пота пахаря. В жарком мареве над полями они собираются и дико таниуют, создавая небольшие вихри. Полуденницы не любят, когда на них кто- 
то смотрит. Те, кто за ними подсматривает, должны с ними танцевать. Полуденницы прекращают танцевать, когда солние клонится к закату, а похищенный человек уже давно мертв от страха и изнеможения» (БРЛИ). В некоторой степени отличается от оригинального образа, где отсутствует мотив танцев, которым заменен оригинальный мотив полевой работы. В традиционном восприятии полудницы - «полевые духи, в частности воплощеене солнечного удара. П. представляли в виде девушки в белом платье, с длинньми волосами или косматой старухи, появляющейся в поле (обычно во ржи: другое русское название П.- "ржаница») и преследующей тех, кто работает в поле» (МФС 1990:672).

\section{Замененные образы}

\section{Кикимора (кикимора-вочн, кикимора-королева, кикимора-рабочий)}

В БРЛИ «Ведьмак» встречаем следующее описание кикимор:

«Кикиморы это живое оскорбление богов, самые уродливые твари на свете. Они отвратительны в силу своей схожести с пауками, и даже самые мелкие из них - рабочие - смертельно опасньл» (БРЛИ).

В русской локализации игры кикиморы - инсектоиды, которые живут в иерархической системе, напоминающей систему муравьев - королева, рабочие, воины. Упоминается еще, что «От кикимор-воинов несет болотным запахом» (БРЛИ).

Этот образ полностью противоречит традиционному представлению о кикиморе. В русской традиции кикимора антропоморфное существо. Это злой дух восточнославянской мифологии, маленькая, уродливая женщина. Живет она либо в человеческих домах, либо на болотах (кикимора болотная). В МФС Мелетинского упоминаются некоторые основные характеристики кикиморы:

1. по ночам беспокоит маленьких детей;

2. может выжить хозяев из дома;

3. враждебна мужчинам;

4. может вредить домашним животным, в частности курам;

5. путает пряжу (сама любит прясть или плести кружева - звуки ее прядения в доме предвещают беду); (по МФС 1991)

Помимо болотного запаха, который отсылает мифонимом кикимора из «Ведьмака» к болотной кикиморе, можно найти еще одну очень отдаленную связь между славянской мифологемой и игровой кикиморой за счет пятого пункта «путает пряжу». Прядение с древних времен ассоциировалось с пауками.

\section{Кащей}

В славянской мифологии встречаем образ Кащея (Кащея Бессмертного) злого чародея. В русской локализации игры «Ведьмак» тоже появляется кащей, но он искусственное создание, которого создал могущественный чародей. Тут кащей инсектоид.

Славистика XXII/2 (2018) 
В этих двух случаях возникает вопрос можно ли вообще говорить о славянском образе. Здесь присутствует славянский мифоним, за которым - неславянский, авторский образ.

Анализ примеров привел к следующим выводам:

1. Мифонимы в БРЛИ встречаются только в искаженном виде. Никогда полностью не соответствуют мифологеме, характерной для русской языковой картине мира.

2. Часто образ искажается сознательно, чтобы придать ему больше «темных красок» и сблизить с монстрами.

3. Наблюдается тенденция смешивания славянского образа с западноевропейским.

4. Часто используется существующий в русском языке мифоним славянского происхождения, но за ним совсем другая мифологема.

Все это указывает влияние на втором уровне языковой личности русскоязычного игрока - а именно лингвокогнитивном, где из понятий, идей и концептов складывается картина мира. К чему это приведет, в действительности сможем проследить, наблюдая и исследуя уже самих игроков в процессе их развития.

\section{Цитирана литература}

Арестова, Д. В. «Миф в творчестве Анджея Сапковского». [В:] А. В. Подчиненов (ред.) Дергачевские чтения - 2011. Русская литература: национальное развитие и региональные особенности: материалы X Всерос. науч. конф., посвящ 100-летию со дня рождения И. А. Дергачева. Екатеринбург: Из-дво Урал унта, 2012, 244-251. [Электронный научный архив УрФу] <http://elar.urfu.ru/ bitstream/10995/20315/1/dc3-2011-39.pdf>30.10.2018

Јоцић, Милош. «'Вештац’ и 'Вештац’ - један текст у два медијума (Механизми интерактивне адаптације фантазијских романа и приповедака Анджеја Сапковског у случају серијала видео игара «The Witcher»)». [В:] Слов'янська фантастика. Збірник наукових праць. Том 3. Київ: Освіта України, 2016, 297-314.

Караулов, Юрий Н. Русский язык и языковая личность. Москва: Издательство ЛКИ, 2010.

Матвиенко, Елена. В. «Языковая репрезентация образов восточноазиатской мифологии в англоязычных текстах - Автореферат». [DisserCat - электронная библиотека диссертаций] <http://www.dissercat.com/content/yazykovayareprezentatsiya-obrazov-vostochnoaziatskoi- mifologii-v-angloyazychnykhtekstakh>25.01.2018.

Мелетинский, Елеазар М. Мифологический словарь. Москва: Советская энциклопедия, 1991.

Пропп, Владимир Я. «Гл. ІІІ: Таинственный лес». [В:] И. В. Пешков (ред.) Исторические корни волшебной сказки. Москва: Лабиринт, 2000, 36-89.

Степанов, Юрий. С. Константы. Словарь русской культуры. Опыт исследования. Москва: Школа «Языки русской культуры», 1997. 
Garda, Maria. «Gra The Witcher w uniwersum Wiedźmina». [In:] Homo Ludens. 1(2), 2010. [Digital edition] <http://ptbg.org.pl/HomoLudens/bib/37/30> 30.10.2018.

Zaborowski, Paweł. «Mitologia słowiańska w cyklu o wiedźminie». [In:] R. Dudziński, A. Flamma, K. Kowalczyk, J, Płoszay (eds.) Wiedźmin polski fenomen popkultury. Wrocław: Stowarzyszenie Badaczy Popkulturyi Edukacji Popkulturowej Trickster, 2015, 21-33. [Digital edition] <http://www.ifp.uni.wroc. $\mathrm{pl} /$ data/files/pub-9860.pdf $>30.10 .2018$.

\section{Источники}

МФС:Мелетинский,Елеазар.М.Мифологическийсловарь. Москва:Советскаяэнциклопедия, 1990.[ЭлектронныйресурсБиблиотекарь.py]<http://bibliotekar.ru/ mif/index.htm> 28.02.2018

БРЛИ: Бестиарий русской локализации игр из серии «Ведьмак». [Официальный сайт игры] $<$ http://thewitcher.com/en/witcher1>28.02.2018

Елица Миланова

\section{ИЗОБЛИЧЕНОСТ ЛИКОВА СЛОВЕНСКЕ МИТОЛОГИЈЕ У КОМПЈУТЕРСКИМ ИГРАМА}

(из угла руске језичке слике света)

\section{Резиме}

У раду се разматра изобличеност ликова из словенске митологије у компјутерским играма под називом „Вештац” са становишта руске језичке слике света. Упоређује се приказ словенских митонима у бестијаријуму игре и традиционални доживљај тих ликова у митској слици света Руса.

Кључне речи: митоним, митологема, руска митска слика света, словенска митологија, компјутерске игре, изобличеност. 